\title{
Invasion of the Indo-Pacific blenny Omobranchus punctatus (Perciformes: Blenniidae) on the Atlantic Coast of Central and South America
}

\author{
Oscar Lasso-Alcalá ${ }^{1}$, Jorge L. S. Nunes², Carlos Lasso ${ }^{3}$, Juan Posada ${ }^{4}$, \\ Ross Robertson ${ }^{5}$, Nivaldo M. Piorski ${ }^{6}$, James Van Tassell ${ }^{7}$, Tommaso Giarrizzo ${ }^{8}$ \\ and Guilherme Gondolo9
}

We examined 308 specimens of the Indo-Pacific blenniid Omobranchus punctatus deposited in four museum collections, and analyzed data on their collection locations to assess its invasion on the Atlantic coast of Central and South America. This species occurs in shoreline estuarine and marine habitats in the Indo-West Pacific. Previous sampling and recent records in the Tropical West Atlantic from 1930 to 2004 produced 20 records for: Panamá, Colombia, Venezuela, Trinidad and Brazil. In this work, we provide data on 17 new records for the Gulfs of Venezuela and Paria in Venezuela, as well as four records for Maranhão and Pará states in NE Brazil. The temporal pattern of collections $(1930$ - 2009) and the proximity of most localities to ports and zones of ship traffic indicate that $O$. punctatus was initially introduced to the Atlantic by ships travelling from India to Trinidad. Within Brazil the introduction is linked to shipping connected to petroleum platforms. In Maranhão and Pará the introduction may have occurred as a result of fish sheltering in fouling on hulls of ships moving between ports around the mouth of the Amazon River. Alternatively, the spread of this species along of the American coast may reflect the expansion of the range of $O$. puntactus through larval dispersal in northward flowing currents. We recommend monitoring of this introduced species, and studies of its ecology in West Atlantic areas.

Nós examinamos 308 espécimes do blenídeo Omobranchus punctatus, de origem Indo-Pacífica, depositados em coleções de quatro museus. Os dados de distribuição foram analisados com o objetivo de avaliar a invasão das águas costeiras do Oceano Atlântico nas Américas do Sul e Central. Em sua área de distribuição original, O. punctatus ocorre em ambientes marinhos e estuarinos. Amostragens datadas de 1930 e de 2004 produziram 20 registros da espécie no Atlântico Oeste tropical, incluindo amostras do Panamá, Colômbia, Venezuela, Trinidade e Brasil. Neste trabalho nós apresentamos 17 novos registros em áreas da Venezuela e nordeste do Brasil. O padrão temporal dos dados (1930-2009) e a proximidade da maioria das áreas de amostragem a regiões portuárias indicam que a espécie foi inicialmente introduzida no Atlântico pela água de lastro de navios navegando na rota India-Trinidade. No Brasil, a introdução parece estar associada ao movimento de navios em torno das plataformas de petróleo. No Maranhão e no Pará, a introdução está associada ao movimento de navios entre os portos próximos à foz do rio Amazonas. Alternativamente, a expansão de área desta espécie ao longo da costa da América pode ter acontecido através de dispersão larval, acompanhando as correntes em direção ao norte. Nós recomendamos o monitoramento desta espécie, bem como o desenvolvimento de estudos sobre sua ecologia em ambientes do Atlântico ocidental agora ocupados por ela.

Key words: Bio-invasions, Distributional data, Exotic marine fishes, New records.

\footnotetext{
${ }^{1}$ Museo de Historia Natural La Salle, Fundación La Salle de Ciencias Naturales. Apartado Postal 1930, Caracas 1010-A, Venezuela. oscar.lasso@fundacionlasalle.org.ve

${ }^{2}$ Universidade Federal do Maranhão, Laboratório de Organismos Aquáticos, Centro de Ciências Agrárias e Ambientais, Chapadinha, Maranhão, Brazil

${ }^{3}$ Programa Biología de la Conservación y Uso de la Biodiversidad, Instituto Alexander von Humboldt, Bogotá, Colombia

${ }^{4}$ Universidad Simón Bolívar, Departamento de Biología de Organismos, Caracas, Venezuela

${ }^{5}$ Smithsonian Tropical Research Institute, Balboa, Panamá

${ }^{6}$ Universidade Federal do Maranhão, Departamento de Oceanografia e Limnologia, São Luís, Maranhão, Brazil

${ }^{7}$ Hofstra University, Deparment of Biology, Hempstead, New York, USA

${ }^{8}$ Universidade Federal do Pará, Laboratório de Biologia Pesqueira, Manejo dos Recursos Aquáticos, Belém, Pará, Brazil

${ }^{9}$ Universidade Estadual do Piauí, Laboratório de Ictiologia, Campo Maior, Piauí, Brazil
} 


\section{Introduction}

Biological invasions are closely related to the history of humanity (Cavalcante \& Major, 2006) and are among the main agents of environmental changes in the world (Occhipinti-Ambrogi, 2007). There is a relationship between environments altered by mankind and the existence of invasive species (Sax \& Brown, 2000). Among marine environments, estuaries are among the ecosystems most altered by anthropogenic actions and are the sites of the greatest number of records of invasions (Moyle et al., 1999).

Wonham et al. (2000) proposed that the invasion of a new environment by an exotic species includes three phases: dispersion, introduction and settlement These phases, along with the survival capacity of the species to its new environment, influence its success as an invader. According to these authors, Blenniids, Gobiids, and Pleuronectids dominate the records of introductions to exotic locations via ballast water because such water provides conditions resembling normal habitats used by them.

The blennies(Blenniidae), comprised about 360 species in 56 genera, are cosmopolitan in tropical and subtropical marine habitats (Nelson, 2006). The natural geographic range of Omobranchus punctatus (Valenciennes, 1836) spans from the northern Indian Ocean to the Western Pacific Ocean. In the 1960s, records of specimens collected in the Atlantic began to be reported, and currently the species is known from the Caribbean and eastern Africa (Cervigón, 1966; Springer \& Gomon, 1975; Cervigón, 1994), Suez Canal and Mediterranean Sea (Bath, 1980; Golani, 2004) and Brazil (Gerhardinger et al., 2006). Omobranchus punctatus is regarded as an exotic species introduced in the Atlantic.

This work was aimed to elucidate the historical information on records of $O$. punctatus on the Central and South Western Atlantic coast, adding new information in order to understand the process of invasion by this species in the region.

\section{Material and Methods}

Two approaches were selected in order to determine the invasion of O. punctatus: (1) field work collections and (2) Museum analyses. For (1) various samplings were done using different fishing methods, such as hand nets and, in some cases, fish poison (Rotenone and Mentol). For (2) an exhaustive bibliographic survey was conducted along, with recisions of fish collections of the following Venezuelan museums such as: Museo de Historia Natural La Salle, Caracas (MHNLS); Museo Oceanológico Hermano Benigno Román, Isla de Margarita, Nueva Esparta State (MOBREDIMAR), and Museo de Ciencias Naturales de Guanare, Guanare, Portuguesa State (MCNG). In addition, the following fish collections were reviewed in Brazil: Deparmento de Oceanografia e Limnologia, Universidade Federal de Maranhão, Maranhão (CPDOL-UFMA); Grupo de Ecologia Aquática, Pará (GEA/UFPA), and Museu Nacional, Rio de Janeiro (MNRJ). The following collections of fishes from the United States were consulted via internet: Academy of Natural Sciences of Philadelphia, Philadelphia, (ANSP); National Museum of Natural History, Smithsonian Institution, Washington (USNM); Natural History Museum of Florida, Gainesville, Florida (UF); Oceanography Institute Scripps, La Jolla, California (SIO); Laboratory of Coastal Investigations of the Gulf Ocean Springs, Mississippi (GCRL); American Museum of Natural History, New York (AMNH), and Natural History Museum, London (BMNH). The other institutional abbreviations mentioned in this essay follow Leviton et al. (1985), except MHNLS, MOBREDIMAR, EBRG, CPDOL-UFMA and Laboratório de Biologia Pesqueira, Universidade Federal do Pará (LBP-UFPA). Other acronyms mentioned in this paper correspond to the ones from Institute of Investigations and Natural Museum Senckenberg (SMF), Frankfurt, Germany and from Hebraic University of Jerusalem (HUJ), Jerusalem, Israel.

\section{Results and Discussion}

A description of Omobranchus genus can be found at Williams (2002). Omobranchus punctatus (Fig. 1) is characterized by having a very elongate rounded head lacking a longitudinal crest on its top; almost always 3 (2-4) pores between the eyes; lateral line with 2-8 double-pored tubes; the gill opening is restricted to above the level of the pectoral fin; dorsal fin XII (XI-XIII), 19-24; anal fin II, 20-26, 1 or both spines imbedded, not visible externally; tail fin with 13 (11-14) segmented rays, none filamentous; a paleedged dark bar across the nape, a little before the origin of the dorsal fin, about 11 dark saddles across the top of the back; 3 dark bars on the lower part of the head and another on the pectoral fin base; and 4-5 slender dark stripes along the upper side of the front half of the body.

The natural range of $O$. punctatus includes the northern Indian Ocean and western Pacific, from the Persian Gulf(Iraq) to India, Japan, the northern Australian coast and the Fiji Islands (Springer \& Gomon, 1975).

In the Caribbean, the first records of O. punctatus was in 1930, when Fowler (1931) described a new species of blenny, Poroalticus sewalli, with specimens captured on the western coast of Trinidad (Brighton beach, Gulf of Paria) (Table 1). In 1975, this species was recognized as a synonym of $O$. punctatus (Springer \& Gomon, 1975). In 1961, Cervigón (1966) recorded $O$. punctatus (as $O$. dasson), at the Guiria on the Venezuelan coast of the same Gulf. After Fowler's initial record (1931), more specimens were collected from Trinidad in 1933, and between 1960 and 1968 (Table 1) for both the Atlantic and Paria coasts of that Island, and the western coast of the Gulf of Paria (Figs. 2a and b).

In Central America, this species has been recorded from Panama, with records of collections between 1967 and 1974 (Fig. 2a, Table 1). All records of the species in Panama come 

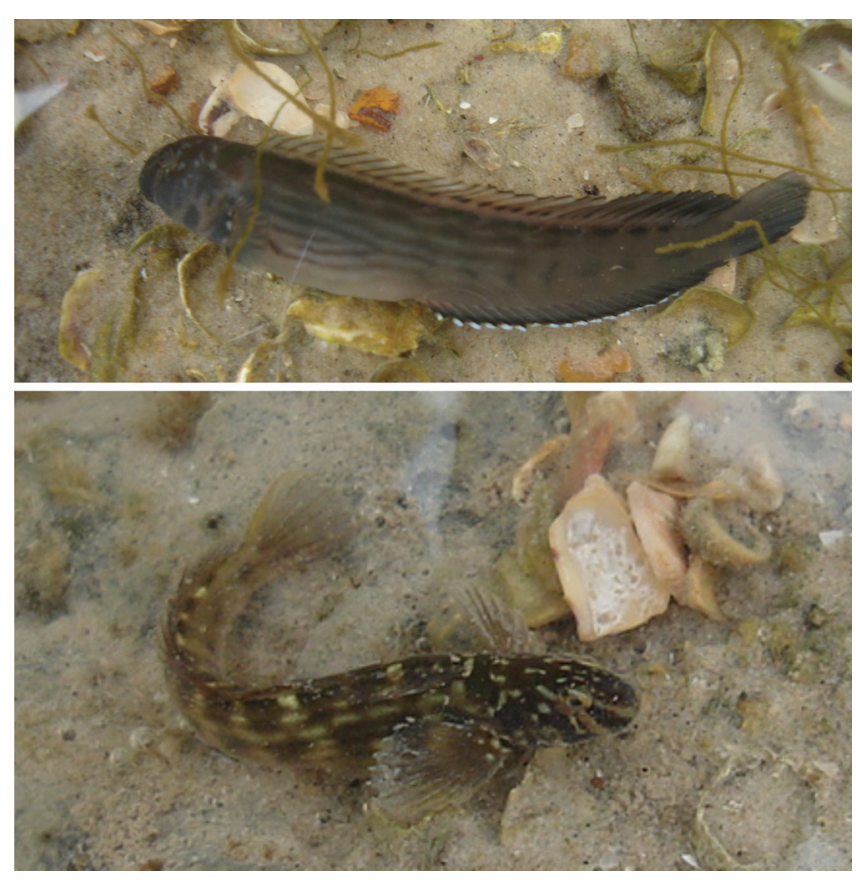

Fig. 1. Omobranchus punctatus in natural habitat (tide pools) in Brazil. Photos by J. Nunes.

from the Caribbean entrance of the Panama Chanel. Fish collections made between 1935 and 1937 at the Pacific side of the Chanel (Miraflores locks) by Hildebrand (1939) yielded no specimens of $O$. punctatus. Also, the species was not recorded in these areas by McCosker \& Dawson (1975). To date, there is no evidence of its occurrence on the Pacific coast of Panama. The Chanel first began operation in 1914. The first record of $O$. punctatus in Trinidad dates from the 1930s. The first records of O. punctatus in Panama, at the Caribbean entrance to the canal, are from 1967, much later than the first record from Trinidad (1930) (Table 1). Springer \& Gomon (1975) and Carlton (1985) suggested that it is likely that specimens of muzzled blenny from Panama originate via shipping movements from the population at Trinidad. This hypothesis was supported by strong similarities in the morphology of specimens collected from those two countries.

The Caribbean coast of Colombia has been intensively sampled over the past 30 years, and as a consequence its shore-fish fauna is well known. Intensive sampling by GarzónFerreira (1989) on the Colombian coast revealed no specimens of $O$. punctatus. To date, the only record of this species (Table 1) on that coast of Colombia is a single specimen from Portete Bay, on Guajira Peninsula, in the eastern end Colombia, just west of the Gulf of Venezuela (Fig. 2c).

There are various records of $O$. punctatus collected in the Gulf of Venezuela, adjacent to the east of Guajira Peninsula (Fig. 2c, Table 1). These include the Gulf itself, and several sites in the channel connecting lago de Maracaibo to the Gulf of Venezuela. Such specimens were captured between 1978 and 2007 and represent new records from this study. The first record of $O$. punctatus from eastern Venezuela was taken by Cervigón (1966) from the Gulf of Paria in 1961 (Table 1). Subsequently, Lasso et al. (2004) collected specimens from a rocky beach of the Orinoco Delta river, in 2002 (Table 1). Other new records from Venezuela are five lots (36 specimens) collected at that same site and a nearby sandy beach in 2004 and 2006 (Table 1). An additional specimen was found in the mouth of Caño Macareo $(68 \mathrm{~km}$ east of the previous location) in 2008 (Table 1), together with 14 specimens from four locations from the eastern end of South coast of the Paria Peninsula. (Fig. 2a; Table 1). One of us (RR), while snorkeling at one of the latter sites, saw dozens of $O$. punctatus darting around a rocky point within $1 \mathrm{~m}$ of the surface of the water. Most recently (April 2009), a specimen was captured inside the shell of a dead barnacle attached to the hull of the ship Boca Grande, $7 \mathrm{~km}$ north of the outfall from Caño Macareo.

The two regions of Venezuela where the populations of O. punctatus evidently are established, the (western) Gulf of Venezuela and the (eastern) Gulf of Paria include the most extensive and important estuary areas of the northern coast of South America. Extensive sampling using small rotenone stations of shallow estuarine and marine habitats between Paria Peninsula and the Gulf of Venezuela by JP, JVT and DRR, between 2005 and 2008 failed to record any specimens of $O$. punctatus. The entrance of lago de Maracaibo and the Gulf of Paria were the only two locations in which $O$. punctatus was collected.

In Brazil, the records of $O$. punctatus date from 2002 and 2008 (Figs. 1 and 2d, Table 1). In 2002, 90 specimens were captured in the Bahia State (Gehardinger et al. 2006). In 2004, Gehardinger et al. (2006) found two specimens in Rio de Janeiro State, and six specimens were collected from fouling organisms on the hull of a ship in Santa Catarina State (Table 1). Here we report new records from the vicinity of the mouth of the Amazon River in 2005 and 2006 (Figs. 1 and 2d Table 1). Most recently, a population was found in Pará State (Fig. 2d, Table 1).

Springer \& Gomon (1975), on the basis of a morphological and historical analysis of the species in the west Atlantic concluded that the populations of $O$. punctatus are the result of an introduction to Trinidad via shipping from India between 1538 and 1914 that transported immigrant workers to Trinidad Island. They thought that ballast water or hull fouling organisms were involved in supporting $O$. punctatus individuals during the voyages.

Information we presented and summarized here, based on collections of $O$. punctatus at additional sites in the Central and NE South American coast also implicates shipping movements in subsequent expansions of that species range. All new collection sites are at or very near to, ports and seaways that support heavy shipping activity: the Gulf of Venezuela and Lago de Maracaibo and the sites in NE Colombia. In this regard, the absence of records of $O$. 
Table 1. Records of Ombranchus punctatus from Trinidad (T), Panama and Colombia (PC), Venezuela (V) and Brazil (B). References from: 1 - Fowler(1931), 2 - Springer \& Gomon (1975), 3 - Garzón-Ferreira (1989), 4 - Cervigón (1966), 5 - Lasso et al. (2004), 6 - Gerhardinger et al. (2006), 7 - Loebmann et al. (2010), and 8 - Soares et al. (2011).

\begin{tabular}{|c|c|c|c|}
\hline Collection & Date & Site & Source \\
\hline T1 & 1930 & Brighton bach, Gulf of Paria & 1,2 ANSP 2 lots \\
\hline $\mathrm{T} 2$ & 1933 & Trinidad, Gulf of Paria & 2, BMNH 1 lot \\
\hline T3 & 1960 & Salt Bay, east coast of Trinidad & BMNH 1 lot \\
\hline $\mathrm{T} 4$ & 1961 & Mayaro, Rodix Point, east coast of Trinidad & 2, USNM 1 lot \\
\hline T5 & 1961 & Salt Bay, east coast of Trinidad & 2, USNM 1 lot \\
\hline V1 & 1961 & Guiria, Sucre state, Gulf of Paria & 4, MOBR-EDIMAR 1 lot \\
\hline T6 & 1963 & Chaguaramas Bay, Gulf of Paria & 2, UF 2 lots \\
\hline PC1 & 1966 & Limón Bay, Atlantic coast, Panamá & 2, USNM 1 lot \\
\hline $\mathrm{PC} 2$ & 1967 & Limón Bay, Atlantic coast, Panamá & 2, USNM 1 lot \\
\hline $\mathrm{T} 7$ & 1968 & Salt Bay, east coast of Trinidad & BMNH 3 lots \\
\hline T8 & 1968 & Mayaro, Rodix Point, east coast of Trinidad & BMNH 3 lots \\
\hline PC3 & 1970 & Limón Bay, Atlantic coast, Panamá & 2, SIO 1 lot \\
\hline PC4 & 1971 & Limón Bay, Atlantic coast, Panamá & 2, SIO 1 lot \\
\hline PC5 & 1972 & Gatún locks, Atlantic coast, Panamá & 2, GCRL 2 lots \\
\hline PC6 & 1974 & Gatún locks, Atlantic coast, Panamá & 2, GCRL 2 lots \\
\hline V2 & 1978 & Paraguaipoa, Zulia state, Gulf of Venezuela & FLMNH 1 lot \\
\hline V3 & 1978 & Zapara Island, Zulia state & MCNG 1 lot \\
\hline V4 & 1978 & El Tablazo Bay, Zulia state & MCNG 1 lot \\
\hline PC7 & 1981 & Portete Bay, Península de La Guajira, Colombia & 3, INV - PEC 1 lot \\
\hline V5 & 2002 & Pedernales beach, caño Manamo, Orinoco Delta, Delta Amacuro state & 5, MHNLS 4 lots \\
\hline B1 & 2002 & Todos os Santos bay, Bahia & 6, MNRJ 1 lot \\
\hline V6 & 2004 & Pedernales beach, caño Manamo, Orinoco Delta, Delta Amacuro state & MHNLS 1 lot \\
\hline B2 & 2004 & Ilha Grande bay, Rio de Janeiro & 6, LNEP-UFF 1 lot \\
\hline B3 & 2004 & Babitonga bay, Santa Catarina & 6, MHNCI 2 lots \\
\hline V7 & 2006 & Pedernales beach, caño Manamo, Orinoco Delta, Delta Amacuro state & MHNLS 1 lot \\
\hline V8 & 2006 & Pedernales beach, caño Manamo, Orinoco Delta, Delta Amacuro state & MHNLS 1 lot \\
\hline V9 & 2006 & Pedernales beach, caño Manamo, Orinoco Delta, Delta Amacuro state & MHNLS 1 lot \\
\hline V10 & 2006 & Cotorra island, Orinoco Delta, Delta Amacuro state & MHNLS 1 lot \\
\hline B4 & 2006 & Araçagy beach, Maranhão & CPDOL 1 lot \\
\hline B5 & 2006 & Calhau beach, Maranhão & CPDOL 1 lot \\
\hline B6 & 2006 & São Marcos beach, Maranhão & CPDOL 1 lot \\
\hline V11 & 2007 & Santa Cruz, El Tablazo bay, Zulia state & MHNLS 1 lot \\
\hline V12 & 2007 & Palmarejo, Estrecho of Lago de Maracaibo, Estado Zulia & AMNH 1 lot \\
\hline V13 & 2007 & Isla de Pájaros, Estrecho of Lago de Maracaibo, Estado Zulia & AMNH 1 lot \\
\hline V14 & 2008 & Punta Pescador beach, caño Macareo, Orinoco Delta, Delta Amacuro state & MHNLS 1 lot \\
\hline V15 & 2008 & Cariaquito inlet, Paria Peninsula, Sucre state & MHNLS 1 lot \\
\hline V16 & 2008 & South of Cariaquito inlet, Paria Peninsula, Sucre state & MHNLS 1 lot \\
\hline V17 & 2008 & Lagoon, Patao inlet, Paria Peninsula, Sucre state & MHNLS 1 lot \\
\hline V18 & 2008 & Patao Point, Paria Peninsula, Sucre state & MHNLS 1 lot \\
\hline B7 & 2008 & Ilha da Romana, Pará & LBP-UFPA 1 lot \\
\hline B8 & 2008 & Luís Correia, Piauí & 7, UFBA 1 lot \\
\hline B9 & 2008,2010 & APA Algodoal-Maiandeua, Pará & 8 , MPEG 8 lot \\
\hline V19 & 2009 & $\begin{array}{c}\text { Boca Grande Ship, } 7 \text { km North Punta Pescador, caño Macareo, Orinoco Delta, Delta } \\
\text { Amacuro state }\end{array}$ & MHNLS 1 lot \\
\hline
\end{tabular}

punctatus on the Venezuelan coast between the Gulfs of Paria and Venezuela, on the Panama coast, east of the Panama Chanel, and along most of the coast of Colombia are particularly revealing. Gehardinger et al. (2006) and Hostim et al. (2002) linked recent records of this species at sites on the east coast of Brazil to ship movements and shipping supply of offshore oil platforms. On the NE coast of Brazil, the collection sites reported here support heavy shipping. However, some expansion of the geographic range of $O$. punctatus through larval dispersal on nearshore ocean currents may well be involved in expansions along the eastern coast of South America: the south Equator Current flowing across the Atlantic bifurcates when it meets the hump of Brazil, with the North Brazil Current flowing along the coast to the
Caribbean, and the South Brazil current flowing south to about the tropic of Capricorn. These currents are thought to be important in promoting dispersal of reef fishes (e.g. Rocha, 2003). The former could be involved in spreading $O$. punctatus along the NE coast of Brazil and the latter in spreading it along the southern Brazilian coast.

Although it is hard to know the natural distribution of $O$. punctatus (Jeffrey Williams, personal communication, 2009), there are records of likely introductions of this species elsewhere in the world. Springer \& Gomon (1975) noted that specimens captured at Mozambique in 1951 and 1970 likely came from a population introduced by ballast water. Subsequent captures at Kenya (USNM 293027) and the southern tip of South Africa (BMNH 1979.3.23.57) likely 

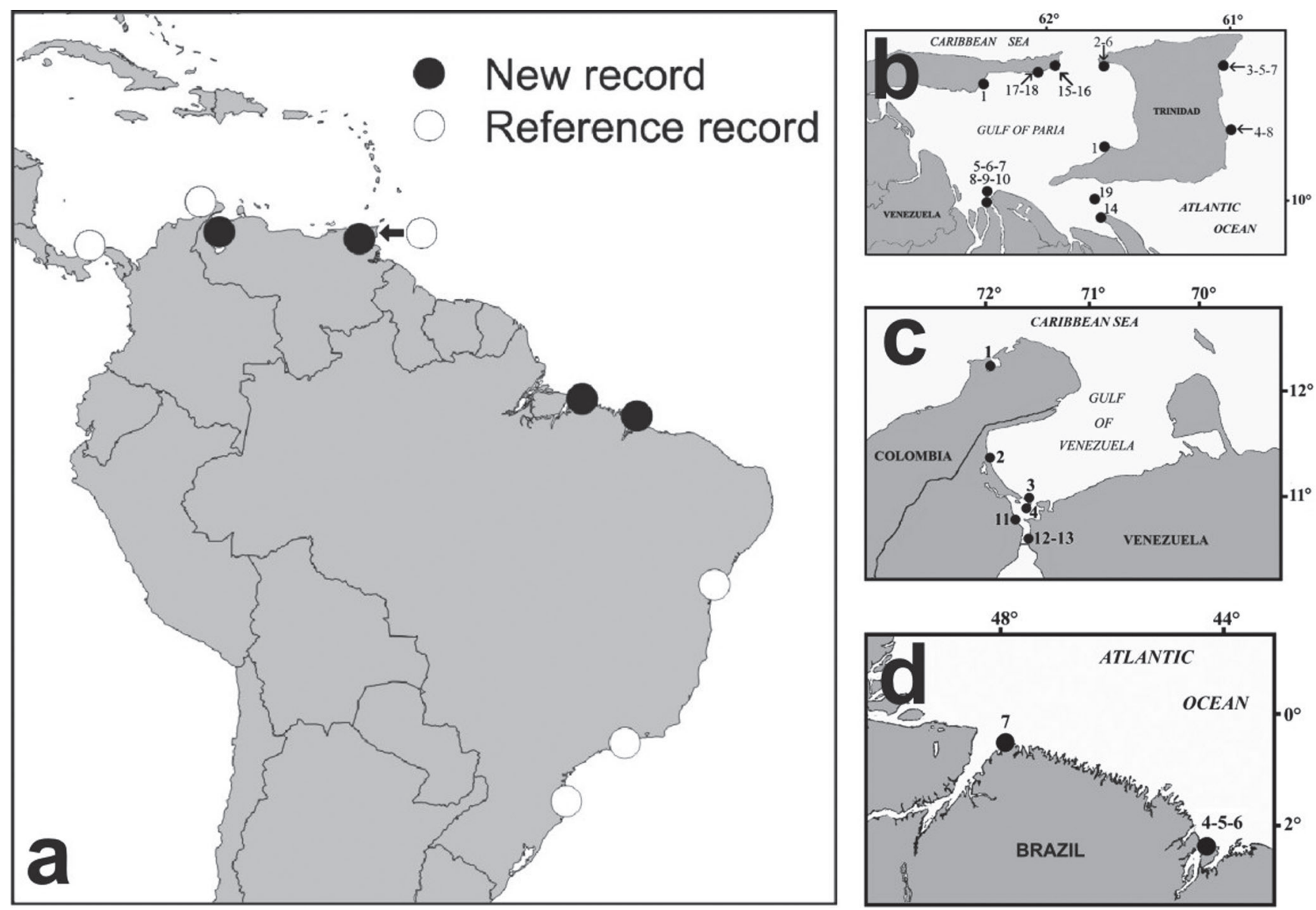

Fig. 2. Distribution of Omobranchus punctatus in Central and South American coasts. a) Full circle represents new records and open circle represents records from literature; b) Catch sites of Omobranchus punctatus in the eastern coast of Venezuela (Gulf of Paria) and Trinidad (see Table 1); c) Localities with records of Omobranchus punctatus in western Venezuela (Gulf of Venezuela) and Colombia (Guajira Peninsula) (see Table 1) and d) Localities with records of Omobranchus punctatus from Maranhão and Pará states, northern Brazil (see Table 1).

resulted from the same or later introductions. Bath (1980) recorded O. punctatus (SMF 15218) captured in 1979, within the Suez Canal, between the Mediterranean Sea and the Red Sea, while Golani (2004) records it (HUJ 18977), on the Mediterranean coast of Israel.

In addition to $O$. punctatus, introductions of three other members of the same genus have been recorded: O. elongatus in Hawaii in 1951 (Walford \& Wicklund, 1973), and subsequently, in Guam in 1992 (Eldredge, 1994), O. obliqus in Hawaii and Kiribati (Myers, 1991) and O. ferox (Herre, 1927) in continental waters from the United States since 1998 (Bartley, 2006). All those introductions are regarded as having led to the establishment of resident populations, potentially leading to competition with native species (Albins \& Hixon, 2008).

Other exotic species have been introduced to the southern Caribbean Sea. Pezold \& Cage (2002) found Eleotris picta (Eleotridae), from western Venezuela. Its natural distribution encompasses the Pacific coast of the America between Mexico and Ecuador. Lasso-Alcalá et al. (2005a) and Lasso-Alcalá et al. (2005b) found the eleotrid Butis koilomatodon and the gobiid Gobiosoma bosc, near the capture points of O. punctatus on the north side of the Orinoco Delta River. Butis koilomatodon, which naturally occurs from east Africa to the West Pacific (Papua New Guinea) (Dawson, 1973; Miller \& Wongrat, 1990), had also been collected from the Pacific side entrance (Miraflores locks) to the Panama Chanel (Dawson, 1973), Western Central Atlantic: Port Harcourt, Nigerie (Miller et al., 1989), Boffa, Guine (Harrison et al., 2003) and mouth of Ndian river in Cameron (Stiassny et al., 2008). The natural range of Gobiosoma bosc is the north west Atlantic, from the western Gulf of México to Massachusetts, on the Atlantic coast of the US (Bohlke \& Robins, 1968; Castro-Aguirre et al., 1999; Williams, 2002).

In the last ten years, the Indo-Pacific lionfishes Pterois volitans (Linnaeus, 1758) and P. miles (Bennett, 1828) have been recognized as the most alarming cases of introduction 
and invasion in the Western Atlantic (Schofield, 2009). From 1999 to 2010, the dispersion of Pterois volitans is confirmed on the east coast of US (New York to Florida), Bermuda, North Caribbean (Bahamas to US Virgin Islands), Gulf of México (Florida and Yucatán Peninsula), Western Caribbean (México, Belize, Honduras, San Andrés and Providencia Arquipelago, Costa Rica, Panama) and South Caribbean Sea (Colombia coast, Curaçao and Bonaire islands) (Whitfield et al., 2002; Chevalier et al., 2008; Guerrero \& Franco, 2008; González et al., 2009; Schofield, 2009; USGS-NAS, 2010; Aguilar-Perera \& Tuz-Sulub, 2010). In Venezuela, this species has been recently observed and collected in 18 locations at the coast and islands of the central region (Lasso-Alcalá \& Posada, 2010).

In Brazil, Caires et al. (2007) found the batrachoidid Opsanus beta, in several sites in southern Brazil (in São Paulo and Paraná States), to where it is thought to have been introduced in ship ballast water.

We recommend performing research focused on inventories of coastal regions near port and aquiculture facilities or with intense maritime traffic to seek other introduced species in Central and South America. Monitoring and studying the bio-ecology of the introduced species and already established populations of Omobranchus punctatus is also recommended. In addition, studies on population dynamic (population structure, reproduction, diet, age and growth), macroecology, behavior, competition with native species, habit use and genetic variation will provide informations to a complete monitoring of the $O$. punctatus.

Material Examined. Omobranchus punctatus. Brazil: Maranhão: CPDOL 6612, 6613, 6614, 6615, 6616, 6617, 6618, Araçagy beach, tidepool, São Luís Municipality; CPDOL 6619, 6620, 6621, São Marcos beach, tidepool, São Luís Municipality; CPDOL 6622, 6623, 6624, Calhau beach, tidepool, São Luís Municipality. Pará: GEA 1255, Ilha da Romana, tidepool, Curuça Municipality. Venezuela: Delta Amacuro: MHNL 17216, 17217, 17218, 17219, 17220; 20728, 21460, 21277, Playa de Perdernales, tidepool; MHNL 21470, Playa Arenosa, tidepool. MHNL 22768, Playa Punta Pescador, tidepool. Zulia: MHNL 22483, Santa Cruz, tidepool. AMNH 241423, Palmarejo, tidepool. AMNH 241438, Isla de Párajos, tidepool. MHNL 24615, Casco Del Barco Boca Grande, tidepool. Sucre: MHNL 24525, 24526, Enseada de Cariaquito, tidepool. MHNL 24523, Laguna, tidepool. MHNL 24524, Punta Patao, tidepool.

\section{Acknowledgements}

The present paper represents part of the academic activities by the first author in the Programa Integrado de Estudios de Postgrado en Zoología Agrícola, Universidad Central de Venezuela. Thanks to Fernando Cervigón (UMA), Arturo Acero (UNC-CECIMAR / INVEMAR), Maria Elisabeth de Araújo (UFPE) and Jeff Williams (USNM) for the comments and suggestions on the manuscript. Also to the directors and personnel from the fish collections consulted for their cooperation with the revision of the material and providing information over the records of the species: Juan Carlos Capelo (MOBR-EDIMAR), Donald Taphorn (MCNG), Francisco Bisbal (EBRG), Luz M. MejíaLadino, Gabriel Navas (INV - PEC), Mark Sabaj, John Lundberg (ANSP), Jeffrey Williams, Richard Vari (USNM), Robert Robins, George Burgess (UF), Philip Hastings (SIO), Sara LeCroy (GCRL), Scott Schaefer (AMNH), Patrick Campbell and Oliver Crimmen (BMNH), Paulo Buckup (MNRJ). The Instituto Socialista de Pesca y Acuicultura (INSOPESCA) granted the scientific fishing permits required in Venezuela. T. Giarrizzo acknowledges financial support by the Fundação de Amparo à Pesquisa do Estado do Pará (FAPESPA) (Project number: 137/2008 - Universal).

\section{Literature cited}

Aguilar-Perera, A. \& A. Tuz-Sulub. 2010. Non-native, invasive Red lionfish (Pterois volitans [Linnaeus, 1758]: Scorpaenidae), is first recorded in the southern Gulf of Mexico, off the northern Yucatan Peninsula, Mexico. Aquatic Invasions, 5: 1-4.

Albins, M. A. \& M. A. Hixon. 2008. Invasive Indo-Pacific lionfish Pterois volitans reduce recruitment of Atlantic coral-reef fishes. Marine Ecology Progress Series. 367: 233-238.

Bartley, D. 2006. Introduced species in fisheries and aquaculture: information for responsible use and control (CD-ROM). FAO, Rome.

Bath, H. 1980. Omobranchus punctatus (Valenciennes, 1836) neu im Suez-Kanal (Pisces: Blenniidae). Senckenbergiana Biologica, 60: 317-319.

Bohlke, J. \& C. Robins. 1968. Western Atlantic seven-spined Gobies, with descriptions of ten new species and a new genus and comments on Pacific relatives. Proceedings of the Academy of Natural Sciences of Philadelphia, 120(3): 45-174.

Caires, R. A., H. A. Pichler, H. L. Spach \& J. M. Ignácio. 2007. Opsanus brasiliensis Rotundo, Spinelli and Zavalla-Camin, 2005. (Teleostei: Batrachoidiformes: Batrachoididae), a junior synonym of Opsanus beta (Goode \& Bean, 1880), with notes on its occurrence in the Brazilian coast. Biota Neotropica, 7(2): 135-139.

Carlton, J. T. 1985. Transoceanic and interoceanic dispersal of coastal marine organisms: the biology of ballast water. Oceanography and Marine Biology - an Annual Review, 23: 313-371.

Castro-Aguirre, J. L., H. S. Espinosa \& J. J. Schmitter-Soto. 1999. Ictiofauna estuarino-lagunar y vicaria de México. Mexico D.F., Editorial Limusa, 711p.

Cavalcante, A. \& I. Major. 2006. Invasion of alien plants in the Caatinga biome. Ambio. 35(3): 141-143.

Cervigón, F. 1966. Los Peces Marinos de Venezuela. Primera Edición. Tomo II. Monografía N ${ }^{\circ}$ 12. Caracas, Fundación La Salle de Ciencias Naturales, 436p.

Cervigón, F. 1994. Los peces marinos de Venezuela. Tomo III. Caracas, Fundación Científica Los Roques, 295p.

Chevalier, P., E. Gutiérrez, D. Ibarzal, S. Romero, V. Isla, J. Calderín \& E. Hernández. 2008. Primer reporte de Pterois volitans (Pisces: Scorpaenidae) para aguas cubanas. Solenodon, 7: 37-40.

Dawson, C. E. 1973. Ocurrence of an exotic eleotrid fich in Panama with discussion of probable origin and mode of introduction. Copeia, 1973: 141-144.

Eldredge, L. G. 1994. Perspectives in aquatic exotic species management in the Pacific islands. Volume I. Introduction of 
commercially significant aquatic organisms to the Pacific islands. South Pacific Commission, Noumea, 127p.

Fowler, H. 1931. Fishes obtained by the Barber Asphalt Company in Trinidad and Venezuela in 1930. Proceedings of the Academy of Natural Sciences of Philadelphia, 83: 391-410.

Garzón-Ferreira, J. 1989. Contribución al conocimiento de la ictiofauna de la bahía de Porterte, Departamento de La Guajira, Colombia. Triaena, 3: 149-172.

Gerhardinger, L., M. Freitas, A. Andrade \& C. Rangel. 2006. Omobranchus punctatus (Teleostei: Blenniidae), an exotic blenny in the Southwestern Atlantic. Biological Invasions, 8: 941-946.

Golani, D. 2004. First record of the muzzled blenny (Osteichthyes: Blenniidae: Omobranchus punctatus) from the Mediterranean with remarks on ship-mediated fish introduction. Journal of the Marine Biological Association of the United Kingdom, 84: 851-852.

González, J., M. Grijalba-Bendeck, A. Acero \& R. Betancur. 2009. The invasive red lionfish, Pterois volitans, in the southwestern Caribbean Sea. Aquatic Invasions, 4: 507-510.

Guerrero, K. \& A. Franco. 2008. First record of the Indo- Pacific red lionfish Pterois volitans (Linnaeus, 1758) for the Dominican Republic. Aquatic Invasions, 3: 255-256.

Harrison, I. J., P. J. Miller \& F. Pezold. 2003. Gobiidae. Pp. 625666. In Lévêque, C., D. Paugy \& G. G. Teugels (Eds.) Faune des poissons d'eaux douce et saumâtres de l'Afrique de 1'Ouest, Tome 2. Coll. Faune et Flore tropicales 40. Paris, France. Musée Royal de l'Afrique Centrale, Tervuren, Belgique, Museum National d'Histoire Naturalle, Paris, France and Institut de Recherche pour le Développement.815 p.

Hildebrand, S. 1939. The Panama Canal as a passageway for fishes, with lists and remarks on the fishes and invertebrates observed. Zoologica, 24: 15-45.

Hostim, M. S., J. Fontes, P. Afonso, N. Serpa, C. Sazima, J. P. Barreiros \& I. Sazima (2002) Plataformas de petróleo: pontos de encontro de peixes em alto mar. Ciência Hoje, 31: 20-27.

Lasso, C., O. Lasso-Alcalá, C. Pombo \& M. Smith. 2004. Ictiofauna de las aguas estuarinas del delta del río Orinoco (caños Pedernales, Manamo, Manamito) y golfo de Paria (río Guanipa): Diversidad, distribución, amenazas y criterios para su conservación. Pp. 70-84. In: Lasso C., L. Alonso, G. Love \& A. Flores (Eds.). A Biological Assessment and Socio Economical Aspects of the Aquatic Ecosystems of the Gulf of Paria and Orinoco Delta. RAP Bulletin of Biological Assessment, 37. Conservation International, Washington. USA.

Lasso-Alcalá O., C. Lasso, F. Pezold \& M. Smith. 2005b. The mud sleeper Butis koilomatodon (Bleeker, 1879) (Pisces: Eleotridae): First record from the Western Central Atlantic. Revista de Biología Tropical, 53: 211.

Lasso-Alcalá, O., C. Lasso \& M. Smith. 2005a. The first record of the naked gobi Gobiosoma bosc (Lacepède, 1800) (Pisces: Gobiidae) from the north coast of South America. Revista de Biología Tropical, 53: 211.

Lasso-Alcalá, O. \& J. Posada. 2010. Presence of the invasive red lionfish, Pterois volitans (Linnaeus 1758), in the coast of Venezuela, southeastern Caribbean Sea. Aquatic Invasion, 5: S53-S59.

Leviton, A. E., R. H. Gibbs Jr., E. Heal \& C. E. Dawson. 1985. Standards in herpetology and ichthyology: Part I. Standard symbolic codes for institutional resource collections in herpetology and ichthyology. Copeia, 1985: 802-832.
Loebmann, D., A. C. G. Mai \& J. T.Lee. 2010. The invasion of five alien species in the Delta do Parnaíba Environmental Protection Area, Northeastern Brazil. Revista de Biología Tropical, 58(3): 909-923.

McCosker, J. \& C. Dawson. 1975. Biotic passage through the Panama Canal, with particular reference to fishes. Marine Biology, 30: 343-351.

Miller, P. \& P. Wongrat. 1990. Eleotridae. Pp. 952-957. In: Hureau, J., C. Karrer, A. Post \& L. Saldanha (Eds.). Check-list of the fishes of the eastern tropical Atlantic (CLOFETA). Vol. 2. Lisboa-Paris, JNICT, SEI and UNESCO, 683p.

Miller, P., J. Wright \& P. Wongrat. 1989. An Indo-Pacific goby (Teleostei: Gobioidei) from West Africa, with systematic notes on Butis and related eleotridine genera. Journal of Natural History, 23: 311-324.

Moyle, P. B., O. T. Sandlund, P. J. Shei \& A. Viken. 1999. Invasive species; biodiversity management. Based on papers presented at the Norway United Nations UN Conference on Alien Species, 2nd Thondheim Conference on Biodversity, Thondheim, Norway, 1-5 July-1996. p.177-191.

Myers, R. F. 1991. Micronesian reef fishes. $2^{\text {nd }}$. ed. Barrigada, Guam, Coral Graphics. 298p.

Nelson, J. S. 2006. Fishes of the world. New Jersey, Jonh Wiley \& Sons, Inc. Hoboken. 601p.

Occhipinti-Ambrogi, A. 2007. Global change and marine communities: Alien species and climate change. Marine Pollution Bulletin, 55: 342-352.

Pezold, F. \& B. Cage. 2002. A review of the spinycheek sleepers, genus Eleotris (Teleostei: Eleotridae), of the western hemisphere, with comparisons to the West African species. Tulane Studies Zoology and Botany, 31: 19-63.

Rocha, L. 2003. Patterns of distribution and processes of speciation in Brazilian reef fishes. Journal of Biogeography, 30: 1161-1171.

Sax, D. F. \& J. H. Brown. 2000. The Paradox of invasion. Global Ecology. Biogeography, 9: 363-371.

Schofield, P. 2009. Geographic extent and chronology of the invasion of non-native lionfish (Pterois volitans [Linnaeus 1758] and $P$. miles [Bennett 1828]) in the Western North Atlantic and Caribbean Sea. Aquatic Invasions 4: 473-479.

Soares, B. E., R. D. O. Raiol \& L. F. A. Montag. 2011. Occurrence of the non-native blenny Omobranchus punctatus (Valenciennes, 1836) (Perciformes: Blenniidae) in the Amazon coastal zone, Brazil. Aquatic Invasions, 6 (Supplement 1): S39-S43

Springer, V. \& M. Gomon. 1975. Revision of the blenniid fish genus Omobranchus with descriptions of three new species and notes on other species of the tribe Omobranchini. Smithsonian Contributions to Zoology, 177: 1-135.

Stiassny, M., G. Teugels \& C. Hopkins. 2008. The fresh and brackish water fishes of Lower Guinea, West-Central Africa (Poissons d'eaux douces et saumâtres de basse Guinée, ouest de l'Afrique central). Collection Faune et Flore Tropicales 42. Muséum National d'Histoire Naturelle, Paris (France), Musée Royal de 1'Afrique Central, Tervuren (Belgium), Volume 2. Paris, Institut de Recherche pour le Développement. 603p.

USGS-NAS. 2010. USGS Nonindigenous Aquatic Species Database, Gainesville, FL http://nas.er.usgs.gov/queries/ specimenviewer.asp?SpecimenID=261964 (Accessed 10 March 2010)

Walford, L. \& R. Wicklund. 1973. Contribution to a world-wide inventory of exotic marine and anadromous organisms. FAO Fish Tech Pap. 121p. 
Whitfield, P., T. Gardner, S. Vives, M. Gilligan, W. Courtenay, G. Ray \& J. Hare. 2002. Biological invasion of the Indo-Pacific lionfish Pterois volitans along the Atlantic coast of North America. Marine Ecology Progress Series, 235: 289-297.

Williams, J. T., 2002 Blenniidae. Pp. 1768-1772. In: K. E. Carpenter (Ed.) FAO species identification guide for fishery purposes. The living marine resources of the Western Central Atlantic. Vol. 3: Bony fishes part 2 (Opistognathidae to Molidae), sea turtles and marine mammals. Rome, FAO Species Identification Guide for Fishery Purposes and American Society of Ichthyologists and Herpetologists Special Publication. $\mathrm{N}^{0}$ 5.. 599p.

Wonham, M. J., J. T. Carlton, G. M. Ruiz \& L. Smith. 2000. Fish and ships: relating dispersal frequency to success in biological invasions. Marine Biology, 136: 1111-1121.

Submitted September 14, 2010 Accepted July 4, 2011

Published September 16, 2011 